\title{
A Career Success of the Distributors in Multi-Level Marketing (MLM) Company
}

\author{
*Elisabet Siahaan, Prihatin Lumbanraja, Yasmin Chairunisa, M. \\ Universitas Sumatera Utara, Medan, Indonesia \\ *elisabeth.siahaan.dr@gmail.com
}

\begin{abstract}
Nowadays, MLM Company around the world are highly developed, and companies especially in Indonesia have been using a system of direct sales to the consumers. The career structure in MLM Company has been very much acknowledged. However, not all MLM distributors are able to achieve the line of succession. The purpose of this research is to analyse the main causes of career success in MLM Company. This study uses both quantitative and qualitative methods. The selection of samples is carried out using a snowball technique which retrieved as many as 198 distributors registered at the Multi-Level Marketing (MLM) Company in Medan, namely; PT. Herbalife Indonesia, PT. Orindo Ayu (Oriflame), PT. Sophi Martin Indonesia, PT. K-link, PT. Tupperware Indonesia and PT. Amway Indonesia. The result of the study finds that entrepreneurial competency and committment simultaneously have a significant influence to the career success of MLM distributors. Moreover, the study finds a partial relationship between the entrepreneurial commitment and motivation that has a significant effect on career success, while the entrepreneurial competency does not partially influence the success of career significantly. The results also show that entrepreneurial motivation is a moderating variable that is able to strengthen the influence of the entrepreneurial commitment to career success, as well as between the entrepreneurial competency and career success.
\end{abstract}

Keywords: Entrepreneurial competency, entrepreneurial commitment, entrepreneurial motivation, career success, Multi Level Marketing (MLM)

\section{Introduction}

The total unemployment in Indonesia up to August 2012 had reached 7.244.956 million people (BPS, 2012). One of the best alternatives in solving this problem is by way of entrepreneurship. One form of the solutions is to resolve the issue by creating entrepreneurial ventures. Among the example of the ventures is to be a distributor of Multi-Level Marketing (MLM) which does not require much in capital and also is not time-constraint. Meanwhile, the total number of entrepreneurs in Indonesia relatively small, but there was a positive trend with the expectation that there would be an increase by $2 \%$ of the total population (Soebari, 2008). This has been aligned with a fact that the number of entrepreneurs in the country will have increased significantly to 1.56 \& in 2014, was and it had even increased for the past three years by $0.18 \%$. With this, the government, through the Ministry of Cooperatives and SMEs, move forward with the National Entrepreneurship Movement (GKN) to increase the number of entrepreneurs which is dedicated to reduce unemployment and poverty. The option to become entrepreneurs through MLM requires competency in terms of creativity, innovation, the ability to motivate oneself and others, the courage to take risks as well as to encourage the changes in the career development. However, the problems may still occur with the distributor's career development in the MLM company, for instance; entrepreneurial competencies are still far from the expectations, also seeing the inability of those distributors in motivating its downline and the distrust of prospective buyers for using their products. Only a small number of product users are turning to become MLM distributors. This leads to the inhibition of the distributors' career success in Multi-Level Marketing Company.

The entrepreneurial commitment is referred as one of the key success of an entrepreneur. It is an attitude that must be owned by an entrepreneur or distributor, while the commitment's phenomenon in MLM does not emerge. The high commitment does not merely sell ideas and concepts, but rather get involved in a whole process of each businesses-related matter with the presence of ancillary factors that utilize the functionality of high-commitment attitude. Given the above arguments, this study has formulated several objectives of study as follows:

- To analyze the effect of entrepreneurial competency, entrepreneurial committment and entrepreneurial motivation towards career success of the distributors in Multilevel Marketing Company. 
- To analyze the ability of entrepreneurial motivation in strengthening the influence of entrepreneurial competency variable towards the career success of the distributors in Multi Level Marketing Company.

- To analyze the ability of entrepreneurial motivation in strengthening the influence of entrepreneurial commitment variable toward the career success of distributors in Multi Level Marketing Company.

\section{Literature Review}

Entrepreneurial Competency: The competency refers to the knowledge or skills needed to produce an outcome, or an internal capability that is used in working activities (Mc Lagan \& Suhadolink in Lertwannawit et al., 2009). Meanwhile, the entrepreneurial competency that is considered useful consists of skills (technical and business), attitude and personal qualities/self entrepreneurship such as creativity and initiated enthusiasm (Hisrich \& Peters, 2002). Moreover, Hirsch and Peters (2002) state that the skills required by entrepreneurs are classified into technical, business management and personal skills. The technical skills include writing, oral communication, environmental monitoring, technical aspects on business management, technology, interpersonal and organizational skills, while the business management skills include planning and goal setting, decision-making, public relations, marketing, finance, accounting and management, and the personal skills include self-discipline, risk-taking, innovative, change-oriented, persistent, and having visionary leadership.

Entrepreneurial Commitment: Meyer and Allens in Clercq and Ruis (2007) refer to the concept of commitment as affective, normative and continuous commitment. Both affective and normative commitment refer to the personal emotional bond to the organization. The affective commitment is related to a person's emotional attachment and identification to the organization, while the normative commitment is associated with a person's belief or loyalty to the organization, so that the employees would feel obliged to remain in the organization. Moreover, the continuance components means the components are based on employees' perceptions about the losses they would face if they left the organization. This is supported by the statement in Malewcki (2003), who mentioned that the commitment is seen as a motivation phenomenon in the context of entrepreneurial networking in the organizations, as well as an attachment to the organization. He also found that the committment has three continuous affective and normative components. The items of instruments to measure commitment which are called as continuance by Mayer and Allens theory, are defined as the perceived costs or loss if ones left the organization. Overall, the shape of these commitments tends to be based on the interests of a person towards a relationship. Meanwhile, affective commitment focuses on emotional attachment that refers to the amount of good feeling and attitude shown by members of the organization. In contrast, the normative commitment means the extent of a moral responsibility of organizational members to maintain their relationship with the organizations.

Entrepreneurial Motivation: Rotenbegr-Shir and Weneberg (2011) define the entrepreneurial motivation by adopting a theoretical goal setting theory that is solely focused on the motivation of entrepreneurial career, which considers a specific task and the goal direction as the core indicators of entrepreneurial motivation. Therefore, the entrepreneurial motivation becomes higher due to the emergence of social problems, namely; unemployment or psychological factors such as the need for achievement. The entrepreneurial motivation is also explained as a procedure or something to do with the results, but on the other hand, it can also be interpreted as intrinsic and extrinsic motivations. Thus, it concludes that entrepreneurial motivation is someone's drive to push himself to become an entrepreneur. In the meantime, an entrepreneurial motive that is most commonly reported in the literature is the desire to be your own boss or work independently (Hundley, in Taormina \& Lao, 2007). Moreover, generating money is an important motivation for every entrepreneur, however, it is not merely the money that can motivate the entrepreneurs. The motivational factors are broadly grouped into two categories; internal factors that include family background, education, training, experience etc; external factors that include raw material, product demand, financial etc. Meanwhile, the entrepreneurial motivation is also grouped into three which are based on necessity, facilities and ambition (Badi \& Badi in Gunu, 2010)

The Career Success: The career success is seen as a tool to meet the needs and desires of a person through achievement, completion and acquisition of power (Lau \& Shaffer in Lertwannawit et al, 2009). The study of career success has been dominated by two competitive perspectives, namely; structural and individualistic. The individualistic perspective argues that career aspirations is the main agent for 
determining a career, which includes knowing the strengths and an individual interest, but not much about the career system in an organization (Aryee et al. in Kristyanto, 2005). On the other hand, based on a job (structural) perspective, the entrepreneurs' career success differs from the general employees, such as the fact that promotion and employment levels are often used as a dimension of career success, however, these are not suitable for the assessment of entrepreneurial success because they are generally categorized as business owners who usually have a position at the top level (Lau, 2007). Moreover, based on the cultural view, although it is believed that a career success is known popularly and considered as a crucial point at every level of the society, the content of career success can change, depending on the geographical and cultural functions. Traditionally, career success had been conceptualized in the form of objective and subjective aspects. The objective career success (extrinsic) is often measured in terms of income, promotion, position, status and reputation (Nicholson \& de Wal-Andrews in Lau, 2007), while subjective career success (intrinsic) refers to the individual assessment of their career experience (Judge et al. in Lau, 2007).

The Multi-Level Marketing (MLM) Company: The purpose of adopting the Multi Level Marketing (MLM) is to disseminate products as well as prosper its employees or commonly called as the distributors. Cahn (2008) has posited that being a direct seller does not require work experience and formal education, but it only needs less capital for investment. Therefore, joining the MLM company is very interesting when other jobs are unavailable. Cahn (2008) also states that the MLM Company like Amway encourage the development of style 'anticorporates' by empowering the workers to be the 'boss' for themselves who will set up their own time. Thus, the advantage of MLM business is having less capital with great opportunities while the future is determined by the distributor itself, and there is no risk of bad loans, there will be free working hours and one will also be able to achieve his or her own dream. MLM is a method of selling goods directly to customers through a network of distributors developed by the chains and tiers. Each distributor recruiting or sponsoring other people is called a partner (downline) who is always associated with bonuses and commissions, and every MLM company has its own calculation method. The MLM distributors are independent business people who earn from their activities of selling the products and capturing partners' activity. The working manners of MLM entrepreneurs are done without such regular working hours in an office, where many of them are working after office hours to earn extra income.

Conceptual Framework: Based on a study done by Chreptaviciene \& Starkute (2012), it is found that career development is influenced by the competencies possessed by a person in an organization. The level of competency should be developed along with the increase in one's career. However, the high competency which is not supported by the commitment will not be able to make an entrepreneur's career succeed. This makes the commitment useful to maintain the business, grow the business and the willingness to sacrifice or invest is able to provide a strong boost to a person's performance in conducting the business relationship. Traditionally, the career was completely determined by the training programs that had been attended by a worker and the opportunities provided by the employer. However, this has been changed whereby, a career success is determined by the workers themselves (Kuijpers et al., 2006). People who will be motivated to get involved in business is expected to increase the performance and will provide valuable results (Katzell \& Thompson, in Sugiyanto, 2007). Conclusively, a motivated worker who runs a high level of venture will tend to believe that the level of ventures will give a good assessment. A good assessment will encourage Company to give bonuses and promotions that will satisfy the purpose of the workers.

Figure 1: Conceptual Framework

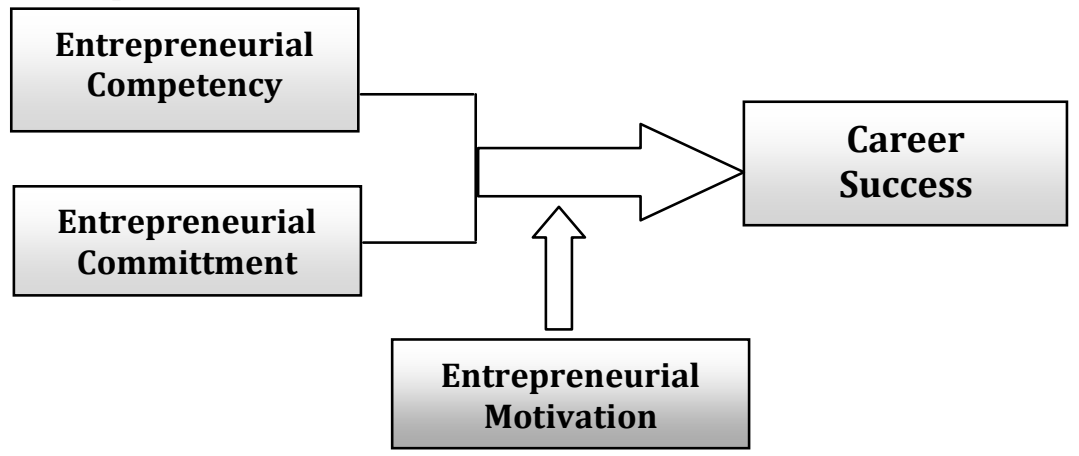




\section{Hypothesis}

- The entrepreneurial competency, commitment and motivation significantly influence the career success of the distributors in Multilevel Marketing company.

- The entrepreneurial motivation is a moderating variable that can strengthen the relationship between entrepreneurial competency and the distributors' career success in Multi Level Marketing company.

- The entrepreneurial motivation is a moderating variable that can strengthen the relationship between entrepreneurial commitment and the distributors' career success in Multi Level Marketing company.

\section{Methodology}

Population and Sampling: The population of this study consists of all members (distributors) who have been officially registered in the MLM Company, among others; PT. Herbalife Medan Indonesia, PT. Orindo Ayu Natural (Oriflame), PT. Sophi Martin Indonesia, PT. K-Link, PT. Tupperware Indonesia and PT. Amway Indonesia. The difficulty of finding official data on the number of registered distributors on each of the MLM companies, had caused the actual number of the population to have been unknown. The sampling technique of this study uses a formula of Isac Michel for the unknown population:

$n=\frac{\left(\frac{Z \alpha}{2}\right)^{2} p \cdot q}{e^{2}}$

Note:

$$
\begin{aligned}
& \mathrm{n}=\text { Sample size } \\
& \mathrm{p}=\text { Population proportion } \\
& \mathrm{q}=1-\mathrm{p}
\end{aligned}
$$

$$
\begin{aligned}
& \mathrm{Z}=\text { Level of confidence } \\
& \text { e = Margin of error }
\end{aligned}
$$

Using the above formula, thus the sample is obtained as follows:

$$
\begin{aligned}
& n=\frac{(1,96)^{2}(0,167)(0,833)}{0,05^{2}} \\
& n=\frac{3,8416(0,1391)}{0,0025}=213,7 \text { or } 214 \text { people/respondents }
\end{aligned}
$$

The sampling technique: The sampling technique in this study uses a non-probability sampling through the purposive snowball approach. Sugiyono (2004) states that a non-probability sampling is a technique that does not provide equal opportunities for each element/member of the population to be elected as the members of the sample. Meanwhile, the purposive sampling is a technique with consideration given to certain criteria, such as the fact that they are the distributors in the MLM Company in Medan. Thus, it obtained the proportion of 0.167 , indicating that there was 1 out of 6 respondents to be found. Moreover, the snowball sampling is a technique whereby at first, a small number of population is involved, then it swells like a snowball rolling to be larger in a long time for a period of time (Sunyoto, 2014). In this research, the first one or two respondents were to be selected, and later they were asked to choose their friends to be the sample, and so on until the desired number of samples was obtained. Despite this, it needs a total of 214 respondents to be asked, however, there were 225 questionnaires distributed to the respondents with the assumption that these excesses would be able to replace the questionnaires that might not be returned or has incomplete dwhich data were incomplete. Upon editing the data on the entire returned questionnaire, the total number of questionnaires that can be used is 198 questionnaires or with the return rate of $92 \%$.

\section{Findings}

\section{Multiple Regression Equation:}

Table 1 finds an equation of the multiple linear regression as follows:

$\mathrm{Y}=\mathbf{- 3 . 8 5 1}+\mathbf{0 . 2 8 7} \mathrm{X} 1+0.015 \mathrm{X} 2+0.303 \mathrm{X} 3+\mathrm{e}$

Based on the above equation, it can be explained as follows:

- Constant (a) $=-3.851$. This shows that if the entrepreneurial commitment, competency and motivation has a zero value, then the career success will decline. 
- Coefficient $\mathrm{b} 1=0.287$. This shows that if the entrepreneurial competency is increasing, then the career success will be increased.

- Coefficient b2 $=0.015$. This shows that if the entrepreneurial commitment increases, then the career success will be increased.

Coefficient $b 3=0.303$. This suggests that if the motivation increases, the career success will be increased.

Table 1: Coefficient

\begin{tabular}{|c|c|c|c|c|c|}
\hline \multirow[t]{2}{*}{ Model } & \multicolumn{2}{|c|}{$\begin{array}{l}\text { Unstandardized } \\
\text { Coefficients }\end{array}$} & \multirow{2}{*}{$\begin{array}{l}\text { Standardized } \\
\text { Coefficients } \\
\text { Beta }\end{array}$} & \multirow[t]{2}{*}{$\mathbf{t}$} & \multirow[t]{2}{*}{ Sig. } \\
\hline & B & Std. Error & & & \\
\hline Constant & -3.851 & 2.191 & & -1.757 & 0.080 \\
\hline TX1 & 0.015 & 0.041 & 0.029 & 0.380 & 0.705 \\
\hline TX2 & 0.287 & 0.053 & 0.451 & 5.402 & 0.00 \\
\hline TX3 & 0.303 & 0.070 & 0.368 & 4.320 & 0.00 \\
\hline \multicolumn{6}{|l|}{$\mathrm{R}=0.811$} \\
\hline \multicolumn{6}{|c|}{ R Square $=0.657$} \\
\hline \multicolumn{6}{|c|}{ Adjusted R Square $=0.652$} \\
\hline \multicolumn{6}{|c|}{ Std. Error of the Estimate $=5.741$} \\
\hline
\end{tabular}

a. Dependent Variable Y

Source: Data Output, 2014

As depicted in Table 2, the value of the adjusted R Square is 0.652 , where this means that the variable of entrepreneurial competency, commitment and motivation contributed as much as $65.2 \%$ on career success of the distributors in the MLM company.

\section{F Test (Simultenous)}

Table 2: F Test (Simultenous)

\begin{tabular}{llllll}
\hline Model & Sum of Squares & Df & Mean Square & F & Sig. \\
\hline Regression & 12274.4774 & 3 & 4091.591 & 124.130 & 0.00 \\
Residual & 6394.680 & 194 & 32.962 & & \\
Total & 18669.455 & 197 & & & \\
\hline
\end{tabular}

a. Predictors: (Constant), TX3, T1, T2

b. Dependent Variable : Y

Based on Table 2, it found the significant value of $0.00 .<0.05$. This suggests that the entrepreneurial competency, commitment and motivation simultenously affect the career success of the distributors in the MLM company.

\section{t Test (Partial)}

Table 3: t Test (Partial)

\begin{tabular}{llllll}
\hline Model & $\begin{array}{l}\text { Unstandardized } \\
\text { Coefficients } \\
\text { B }\end{array}$ & Std. Error & $\begin{array}{l}\text { Standardized } \\
\text { Coefficients } \\
\text { Beta }\end{array}$ & t & Sig. \\
\hline Constant & -3.851 & 2.191 & & -1.757 & 0.080 \\
TX1 & 0.287 & 0.053 & 0.451 & 5.402 & 0.00 \\
TX2 & 0.015 & 0.041 & 0.029 & 0.380 & 0.705 \\
TX3 & 0.303 & 0.070 & 0.368 & 4.320 & 0.00 \\
\hline
\end{tabular}

Dependent Variable : Y

Source: Data Output, 2014

As depicted in Table 3, it can be seen that the entrepreneurial competency has a significant value of $0.00>$ 0.05. This means that entrepreneurial competence partially has a significant effect on career success, while the entrepreneurial commitment has a significant value of $0.705>0.05$. This means that partially, the entrepreneurial commitment has no effect on career success, and entrepreneurial motivation has a signifiant value of $0.00>0.05$. This suggests that partially, the motivation has a significant effect on career success of the distributors in the MLM company. 


\section{Residual Test}

Motivation serves as a moderator between entrepreneurial committment on career success: Motivation functions as a moderator between entrepreneurial committment and career success. This means that a high level of motivation is able to strengthen the influence between entrepreneurial committment on career success.

Table 4: Coefficient Entrepreneurial Committment

\begin{tabular}{|c|c|c|c|c|c|}
\hline \multirow[t]{2}{*}{ Model } & \multicolumn{2}{|c|}{$\begin{array}{l}\text { Unstandardized } \\
\text { Coefficients }\end{array}$} & \multirow{2}{*}{$\begin{array}{l}\text { Standardized } \\
\text { Coefficients } \\
\text { Beta } \\
\end{array}$} & \multirow[t]{2}{*}{$\mathbf{t}$} & \multirow[t]{2}{*}{ Sig. } \\
\hline & B & Std. Error & & & \\
\hline Constant & 7.795 & 1.239 & & 6.291 & 0.00 \\
\hline $\mathrm{Y}$ & -0.066 & 0.032 & -0.145 & -2.053 & 0.041 \\
\hline
\end{tabular}

Dependent Variable : AbsRes_1

Source: Data Output, 2014

Based on Table 4, it is found that Y (career success) has a sig $0.041>0.05$ and a parameter coefficient of negative value, and it concludes that motivation is used as a moderating variable.

Motivation serves as a moderator between entrepreneurial competency on career success: Motivation functions as a moderator between entrepreneurial competency and career success. This means that a high motivation is able to strengthen the influence between entrepreneurial competency on career success.

Table 5: Coefficient Entrepreneurial Competency

\begin{tabular}{|c|c|c|c|c|c|}
\hline Model & \multicolumn{2}{|c|}{$\begin{array}{l}\text { Unstandardized } \\
\text { Coefficients }\end{array}$} & $\begin{array}{l}\text { Standardized } \\
\text { Coefficients } \\
\text { Beta }\end{array}$ & $\mathbf{t}$ & Sig. \\
\hline Constant & 8.969 & 1.185 & & 7.567 & 0.00 \\
\hline $\mathrm{Y}$ & -0.112 & 0.031 & -0.253 & -3.654 & 0.00 \\
\hline
\end{tabular}

a. Dependent Variable : AbsRes_2

Source: Data Output, 2014

Based on Table 5, it is found that Y (career success) has a sig $0.00>0.05$ and a parameter coefficient of a negative value, so it concludes that motivation is used as a moderating variable.

\section{Discussion and Conclusion}

Based on the results of the partial test ( $t$ test), it is known that entrepreneurial competency significantly influences the career success of the MLM distributors. This phenomenon is aligned with the theory stating that the entrepreneurial competency is a very important element in the formation of a businessman's career success as well as towards all types of MLM businesses, as this concept is also fully applicable. In this type of MLM business, independent distributors are fully aware that there are a number of competencies they should possess or master to be able to run the business successfully, and furthermore in order for them to be able to achieve an optimal career. In the MLM company's point of view, its system does require high creativity and innovation from the distributors. Therefore, if an independent distributor has less creativity and does not possess ideas that are always able to be modified to bring new ideas, thus it will be difficult to reach a career peak.

Based on the partial test ( $\mathrm{t}$ test), it is known that the entrepreneurial commitment is related to career success but has insignificant effect. Theoretically, this was the first concept introduced by Porter et al. that defines the organizational committment as a strong belief, acceptance of the organizationals' goals and values and a strong desire to remain in the organization (Porter et al. in Clercq \& Ruis, 2007). If the results of this study are associated with the original concept of commitment, this indicates that any distributor who wants to achieve career success requires high commitment in ventures, or called entrepreneurial commitment. However, many of the respondents considered the career in MLM Company as a side job. Thus, they do not give full commitment in developing their career in MLM Company. Moreover, the partial test results ( $t$ test) show that entrepreneurial motivation significantly influences the career success of the MLM's distributors. If this is associated with a variety of existing theoretical 
concepts of motivation, it is often shown as a strong effort to excel in a variety of activities. This is aligned with the concept of the need for achievement by McClelland which is based on the classical theory of needs, which states the need as a motivator of human behavior. A study by Collins et al. in Rotenbegr-Shir \& Weneberg (2011), also shows that the desire to excel is a predictive entrepreneurial factor.

Based on the residual test, motivation serves as a moderator between entrepreneurial competency and career success. This means that high motivation will be able to strengthen the influence of entrepreneurial competency to career success. One of the needs to obtain achievement is one's career success. The career success is seen as a tool to meet the needs and desires of a person through the achievement, also the completion and acquisition of power (Lau \& Shaffer in Lertwannawit et al., 2009). With high motivation, then the person has high-intensity efforts that are always directed towards meeting the needs in a long period of time, and vice versa. It further explained, although one has a good entrepreneurial competency if his or her motivation is weak, thus certainly the process of achieving their needs (career success) will experience a lot of problems associated with motivation, for example, they will be less diligent, easily discouraged, lack discipline, have low desire for achievement and lack confidence.

Based on the residual test, the motivation also serves as a moderator between entrepreneurial commitment and career success. It means that high motivation will be able to strengthen the influence of entrepreneurial commitment to career success. Since the commitment is seen as a motivational phenomenon in the context of entrepreneurial organization networking, it is actually an attachment to the organization, then the existence of motivation as a moderating variable that can strengthen or weaken the effect of the relationship between entrepreneurial commitment and career success would be highly relevant. This can be explained as follows; if one's motivation is high, then this condition will generally strengthen the commitments that had been there in a person irrespective of whether normative, affective and continuous commitment. If this condition is associated specifically with achieving career success, then this would be strongly related to continuance commitment. The career success in a particular organization will not be achieved if one does not involve himself in the organization within a long period of time.

Finally, this study produces several points as follows:

- Based on the F test, the entrepreneurial competency, commitment and motivation simultanously affect the career success of the distributor in the MLM company.

- Based on the $t$ test, the entrepreneurial competency partially has no effect on career success. Meanwhile, the entrepreneurial commitment to motivation partially has a significant effect on career success.

- Based on the results of the determinant coefficient (R squared), the adjusted R Square was 0.652, which means that the variables of entrepreneurial competency, commitment and motivation had given a contribution of $65.2 \%$ to the career success of the distributors in MLM company.

- The residual test results indicate that entrepreneurial motivation is a moderating variable which strengthens the influence of entrepreneurial competency with a career success of the distributors in MLM company.

- The residual test results indicate that entrepreneurial motivation is a moderating variable that can strengthen the influence of entrepreneurial commitment to the career success of the distributors in MLM company.

\section{References}

BPS. (2012). Survei Angkatan Kerja Nasional. Jakarta, Indonesia: Biro Pusat Statistik.

Cahn, P. S. (2008). Consuming Glass: Multilevel Marketers in Neoliberal Mexico. Cultural Anthropology, Proquest, 429

Chreptaviciene, V. \& Starkute, J. (2012). Relationship Between Career and Competency: Verification of Theoritical Model Validity. Engineering Economics, Kaunas University of Technology, 23(2), 163173.

Clercq, D. D. \& Ruis, I. B. (2007). Organizational Commitment in Mexican Small and Medium-Sized Firms: The Role of Work Status, Organizational Climate, and Entreprenurial Orientation. Journal of Small Business Management, 45(4), 467-490 
Gunu, U. (2010). Entrepreneurship Development in Micro Entreprises As A Medium for Poverty Reduction in Kwara State, Nigeria. Interdisciplinary Journal of Contemporary Research in Business, 2(6), 235-252

Hisrich, R. \& Peters, P. (2002). Entrepreneurship, Fifth Edition. New York: McGraw-Hill Higher Education

Kristyanto, A. (2005). Pengaruh Klik Sosial dan Koneksi Terhadap Kesuksesan Karir Hierarkhi, Jurnal Ekonomi Manajemen, Fakultas Ekonomi, Universitas Kristen Petra, Surabaya.

Kuijpers, M. A. C., Schyns, B. \& Scheerens, J. (2006). Career Competencies for Career Success. National Career Development Association, 55, 268-178.

Lau, V. P. (2007). Entrepreneurial Career Success From a Chinese Perspective: Conceptualization, Operatioanalization and Validation. Journal of International Business Studies, 38, 126-146

Lertwannawit, A., Serirat S. \& Pholpantin, I. (2009). Career Comptencies And Career Success of The Employees in Tourism and HospitalitSector. International Business an Economics, Research Journal, 8, 65-72

Malewcki, D. S. (2003). The Role of Commitment and Trust in Entrepreneur Network Organizations, Thesis, Doctor of Philosophy in Business Administration, Graduate College of the University of Illinois, Chicago.

Rotenberg-Shir, N. \& Weneberg, K. (2011). A Contingency Model of Entrepreneurial Entry Strategies The Role of Motivation and Resource Availability, Centre for Entrepreneurship and Business Creation, Stockholm School of Economics, Sweden.

Soebari, S. I. (2008). Pensiunpreneur: Pensiun Sukses. Jakarta: Penebar Plus.

Sugiyanto, T. (2007). Pengaruh Human Capital, Motivasi dan Dukungan Atasan Terhadap Kesuksesan Karir Karyawan: Studi Empiris di PT. Asian Cotton Bandung. Jurnal Akuntansi, Manajemen Bisnis dan Sektor Publik, 3(3), 333-348.

Sunyoto, L. (2014). Metode Penelitian Ekonomi. Yogyakarta: CAPS.

Sugiyono, L. (2004). Metode Penelitian Bisnis. Bandung: CV Alfabeta.

Taormina, R. J. \& Lao, S. K. (2007). Measuring Chinese Entrepreneurial Motivation: Personality and Environmental Influences. International Journal of Entrepreneurial Behavior and Research, 13(4), 200-221. 